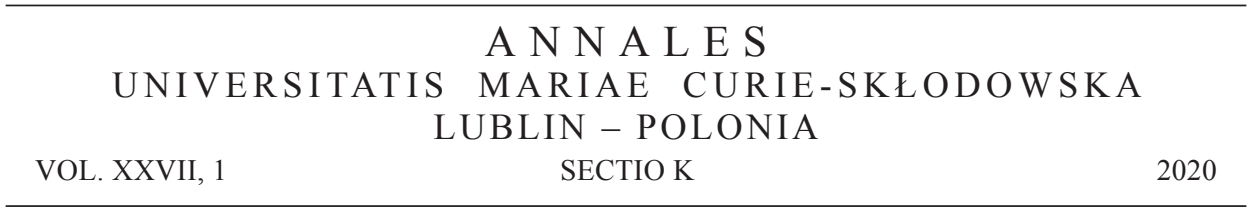

Jagiellonian University. Faculty of International and Political Studies

SIMONA SIENKIEWICZ

ORCID ID: 0000-0001-6311-5057

\title{
Religion and Internal Migrations in the Processes of Indonesianisation and Islamisation of West Papua
}

Religia i migracje wewnętrzne w procesach indonezjanizacji i islamizacji Papui Zachodniej

\begin{abstract}
Internal migrations are a growing problem in multiethnic societies. Indonesia is one of the most diverse countries in the world and home for hundreds of ethnic groups united under the main idea - national identity. But this concept remains unclear for many Indonesians, especially those living outside the central, overpopulated Java and Madura. To achieve the utopian unity, President Suharto (1967-1998) introduced the "transmigration" program, which moved people from overcrowded territories to the so-called "outer islands". The official plans emphasised its economic and development importance, but I argue that transmigration was also a political tool for introducing the processes of Indonesianisation and Islamisation. Using Michael Hechter's theory of internal colonialism, I support my argument with reports and documents referring to the case of West Papua in Eastern Indonesia. The territory with separatist experience and a strong desire for a great autonomy serve as a good example of attempts of deliberate Indonesianisation and Islamisation. An overwhelming number of internal migrants, Javanese Muslims, gradually diluted the unity of Christian Papuans. The lack of balance between these groups creates a constant tension in a changing society. Based on the argument, I explain the influence of internal migration in a wider context. I pay attention to the dynamism of religious and ethnic structure before and after the fall of the New Order regime. I argue that processes of Indonesianisation and Islamisation are crucial for the further existence of Papuans and solutions adopted by the Indonesian state.
\end{abstract}

Keywords: Indonesia, West Papua, Indonesianisation, Islamisation, transmigration 


\section{INTRODUCTION}

The social structure of the western part of New Guinea ${ }^{1}$ represents the rough history of this territory, which has experienced deep changes, especially in the last decades. The most vulnerable areas in this process were ethnicity and religion. To understand their importance, we have to look back on the Papuan's experiences with external actors. In the $19^{\text {th }}$ century, missionaries (both Protestant and Catholic) noticed high potential for their activities on pristine territories of western New Guinea. At that time, the indigenous tribes used own economic systems and followed the local faiths. Europeans and Americans perceived Papuans as "primitives" but encouraged them to religious conversions and commercial exchange. Initially, the indigenous people were reluctant to outsiders. Their trust to external actors started increasing with the economic and administrative support of clergy and merchants. But Papuans were unaware that they were exploited as the part of broader strategies of the Church and the Dutch East Indies.

During the national revolution (1945-1949), Indonesian concept of its borders was based on the legacy of the Dutch East Indies. It included West Papua, whose inhabitants had no idea about the project of the Indonesian state. After intensive disputes, the territory remained under the Dutch control which was an insult to Jakarta. In the next years, Indonesia just waited for a good moment to make a legal takeover. It took place in 1969, when President Suharto (1967-1998) incorporated West Papua into Indonesia in a controversial referendum ${ }^{2}$. The government realized that most of Papuans did not support this action, so it tried to find the way to implement the national philosophy and principles among indigenous people. Jakarta decided to carry on the process of transmigration, which was one of the flagship policies of Suharto. The program provided administrative and economic support for residents of Java, Madura and Bali, who moved to the eastern outskirts of the archipelago. Apart from the physical presence, they also brought their ethnicity and religion - most often Islam.

Indonesian government declared that transmigration would ensure sustainable development in the whole country. But the Papuans perceived mass migrations as

1 The western part of New Guinea has changed its name along with history. During the Dutch rule, it was "Western New Guinea", according to its geographical position. After 1950, Europeans referred to this territory as "Dutch New Guinea", while Indonesians used the term "West Irian". After annexation, Indonesia renamed it "Irian Jaya" ("Victorious Irian"). The fall of the New Order in 1998 divided the western part of New Guinea into two provinces: Papua and West Papua. However, the term "West Papua" is widely used in research about the whole Indonesian part of New Guinea.

2 In 1962, West Papua came under a temporary UN administration (UNTEA) under the New York Agreement. It ordained referendum as a tool to decide about the further status of Dutch New Guinea/West Irian. Indonesians claimed that Papuans were too primitive to choose wisely, so the referendum in 1969 did not have a form of regular voting but a supervised consultation (musyawarah). During this event, 1,026 delegates, who represented the interests of Indonesia, made a decision about joining West Papua to their country [May 1992: 405]. 
the beginning of Indonesianisation. They noticed depreciation of local values and faiths not only among the officials but also among the army and police. The tensions connected with a different perception emerged with the downfall of Suharto's dictatorship in 1998. Riots, which broke out across the country, influenced the harmonious coexistence of all Indonesians. It turned out that the transmigration strengthened differences between people living in the central and so-called "outer islands". Additionally, internal unrest had its impact on the religious issues - the growing power of Islam carried the risk of sectarian conflict in places dominated by Christians.

The influx of internal migrants to West Papua brought the administration closer to Jakarta, but not to the indigenous people. In this paper I show how Indonesian government influenced the ethnic and religious composition of West Papua and why such terms like "Indonesianisation" and "Islamisation" should be taken into account. To make my argument clear, I divided the article into three sections. In the first part, I explain the processes of internal migrations in the context of Indonesianisation. Then, I focus on the changing role of religion in West Papua after the fall of New Order regime. In the last part, I argue that the growing number of Muslims supported Islamisation. The paper ends with the conclusion that the ethnic and religious consequences of internal migrations are decisive for the future of West Papua ${ }^{3}$.

\section{INDONESIANISATION THROUGH TRANSMIGRATION}

The New Order regime (1967-1998) condemned almost all manifestations of ethnicity in Indonesia. It included the indigenous identity of Papuans, which was treated as a manifestation of separatism. The officials considered local traditions as uncivilised and primitive. Papuans were often the victims of mockery and racist attacks of Indonesians from other islands, which was the psychological aspect of Indonesianisation [Tebay 2005: 11]. This process "includes a comprehensive system of programs designed to bring the people of Irian Jaya to the cultural, economic and political life of the Indonesians by assimilating with other ethnic groups and taking part in the cultural, economic and political life of Indonesia" [Roosman 1975: 165].

The situation in West Papua brought me to Michael Hechter's theory of internal colonialism [Hechter 1975: 8-10]. It assumes that the core dominates the periphery in political terms and exploits its resources. The government in Jakarta represents "the core", while West Papua, Moluccas, Lesser Sunda Islands share the status of "the periphery". Internal colonialism means unequal redistribution of resources and development of institutions that bring benefits to "the core". It promotes its supporters in local governments. In West Papua, the internal migration left indigenous com-

3 The present article was written in 2018 so it does not consider the revival of Papuan separatism in 2019 and the response of Indonesian government. 
munities unable to find a voice in decision-making processes. People who decided about the most important issues made agreements profitable to Jakarta, not Papuans.

For the Papuans incorporation to the neighbouring state was like being a part of Weberian compulsory organisation [Weber 1978: 52]. The local nationalists claimed that Indonesianisation came with "depapuanisation". The main purpose of this process was eradicating indigenous cultures and traditions and strengthening Pancasila ${ }^{4}$ (state philosophy), the nationalistic history of the independence revolution, Islam and Javanese lifestyle [Trajano 2010: 18]. Indonesianisation included three main assumptions:

- inculcating the Indonesian worldview - compulsory learning and using Indonesian language, respecting Pancasila and controlling education and the media,

- maintaining contacts among diverse ethnic groups through internal migration to consolidate the unity of Indonesian nation,

- supporting economic development and modernization to weaken the ethnic identity in favour of the national one.

The idea of transmigration supported all these goals [Gietzelt 1989: 202]. Indonesian government implemented this program after the annexation of West Papua. It officially sought to an even distribution of the population in the vast Indonesian territories. But in West Papua, transmigration also became a tool of Indonesianisation and repression against indigenous peoples. The well-organised army, a propagandist state education, nationalism and generous funding for the internal migrants supported the smooth implementation of the program [Farhadian 2005: 25]. In West Papua, there were two kinds of transmigration: transmigrasi umum (with complete financial and logistic support from the government) and transmigrasi swakarsa (people from other islands of Indonesia who migrated to Irian Jaya, reported themselves after arrival and received assistance in basic needs) [Hardjono 1986: 46].

Transmigration deepened the social differences in West Papua. The new settlers immediately got lucrative positions in administration without knowledge about the local background and values. Also, they received the land - previously owned by Papuans - without adequate compensation [Aritonang, Steenbrink 2008: 347]. It undermined the position of indigenous people, for whom the possession of the land was crucial in maintaining their position in an internal social hierarchy. The fact that Papuan territories were rich in natural resources created an additional space for malpractices. In other areas, the migrants, usually Muslims, dominated local markets and discriminated indigenous people. The outsiders preferred to hire other transmigrants. The native inhabitants of West Papua working in state administration, police and army were gradually replaced by newcomers.

The social disparities were very clear in Jayapura - the capital of Irian Jaya which developed into a pro-Indonesian headquarter. Internal migrants took over

4 The five principles of Pancasila, that constitute the basis of the Indonesian state, are: 1) belief in one God, 2) nationalism, 3) humanitarianism, 4) social justice, 5) democracy [Ricklefs 2001: 258]. 
coastal cities, which pushed the indigenous population inland. Because of this tendency they lost many opportunities to progress, especially economic one. Papuans began to feel discriminated against and marginalized in their own land. This took place only within one generation [King 2004: 28]. They observed with concern the growing power of Islam, which used to be the main religion only in a few small villages on the west coast. But Muslims from coastal towns soon dominated Christians because of high rates of birth [Anderson 1983: 488]. Meanwhile, the mortality among infants and young children of indigenous people staying in the hinterland was rather high because of limited access to medical care and sexual education. Transmigration diminished the significance of Christian Papuans and was more effective than the army.

The government reports and statistics never expressed the religious aspect of transmigration. But it was an important aspect in Islamisation of West Papua. Despite the regulations ${ }^{5}$, the officials turned a blind eye to conversions from Christianity to Islam. Muslim preaching is non-institutionalized, different from Protestant or Catholic. The spiritual leaders promoted the message of Islam among the societies, which was not suitable for Papuan environment. Raising new believers among indigenous peoples required knowledge of the regional languages, traditions and beliefs of particular ethnic groups. Protestants or Catholics were better organised in these areas, worked hard gaining complete information about local communities and taught them the Indonesian language. Thus, Islamic preachers waited for a more convenient situation and later encouraged converted Christians to accept their religion for economic benefits. Figure 1 shows the strategy of Muslims.

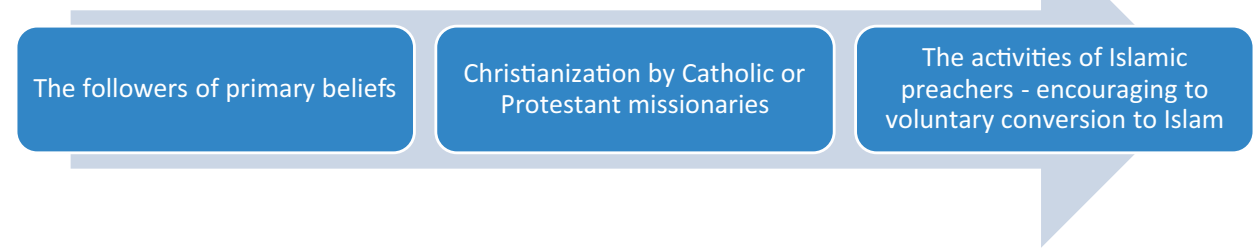

Figure 1. Changes in the religion of indigenous people

Source: Author's own study.

The scattered data do not allow to evaluate ethnic and religious consequences of transmigration for West Papua. Neles Tebay - a clergyman, journalist, researcher,

5 In November 1978, the government introduced a regulation according to which the followers of "global religions" (Islam, Protestantism, Catholicism, Buddhism, Hinduism and Confucianism) cannot carry on missionary activities among people adhering to them. For example, Christians were forbidden to convert Muslims and vice versa [Farhadian 2005: 73; Suter 1982: 11]. 
who spent his life maintaining contacts with indigenous Papuans and pro-Indonesian administration - emphasises the strong influence of both transmigrasi umum and transmigrasi swakarsa on the Papuan society. He estimated that from 1964 to 1999 , almost 550,000 people moved to West Papua from the poorest and most populated areas of Indonesia [Tebay 2005: 14]. This number comprised mostly Javanese and Madurese but also some migrants from Sulawesi, Sumatra (Batak and Minangkabau), Flores, Maluku, Timor and Bali [Aritonang, Steenbrink 2008: 346]. However, other researchers, like Bobby Anderson, claimed that Tebay's data was an exaggeration. According to his statistics, only 220,256 citizens took part in transmigration to Papua between 1964 and 2000 [Anderson 2015: 45]. He believed that this process did not impact on the strengthening position of Islam and there is no official evidence to deliberate implementation of Islamisation and Indonesianisation. This significant difference between opinions of these two researchers (almost 300,000 people) reflects to a great extent the accuracy of the data from the New Order regime oriented to the propaganda of success. The intensity of transmigration along with a complicated situation in Papua allow us to make an assumption that we should rather rely on the overestimated data.

The following factors could explain the difference between Tebay's and Anderson's data. Anderson probably did not consider unregistered waves of family migrations (often the father himself joined the transmigration program, later brought his wife and children) and the high birth rate among Muslim families, which stimulated the demographic growth in West Papua. Perhaps the number of registered transmigrants was not impressive, but it was the second generation that made the biggest contribution to universalising Islamic and Indonesian values. This tendency marginalised the indigenous people, whereas it was convenient for officials in Jakarta because nobody could directly attribute these actions to them. During the New Order, the social tensions deepened in West Papua but the army and police suppressed potential conflicts. It was not until the fall of Suharto that the most serious consequences of transmigration were revealed.

\section{RELIGION IN WEST PAPUA AFTER THE FALL OF NEW ORDER}

The first protests against Indonesian government began in 1996, but the fall of Suharto's regime took place two years later. Enthusiasm came with uncertainty about the future of the country that was highly divided. The new situation was a chance for a greater autonomy or even independence for West Papua. Democratic spirit of 1998 pushed the Catholic and Protestant churches and non-governmental organisations to establish the Forum for Reconciliation of the People of Irian Jaya (FORERI). Its representatives travelled to Jakarta to negotiate the future status of West Papua with President Jusuf Habibie [Rutherford 2008: 359]. 
During one meeting in 1999, a clergyman, Agus Alue Alua, described the situation of Papuans in the following words:

The people of West Papua are threatened with extinction as a result of the political, economic, and social policies promulgated by the Indonesian government over the past thirty-six years. These policies, which don't take the side of the West Papuan people, represent just one element in a series: "systematic violence", "systematic killing", and "systematic destruction", that is, "genocide". The result is that we, the Papuan people, are slated to vanish from the face of this earth. During our thirty-six years of integration with Indonesia, our worth and self-respect have not been valued or honoured; we have not been treated as human beings, creations of God the Almighty Creator. We've been slaughtered like beasts for the sake of preserving Indonesian political stability and unity [Mote, Rutherford 2001: 125].

These words broke a taboo in the public sphere. For the first time in decades, someone openly referred to the brutal activities in West Papua that was an equal part of the Indonesian state, not an occupied territory. The society started to change its attitude towards Papuans. It was visible in small but significant actions. One of them was using the term "Papua" instead of "Irian Jaya" in the censorship-free Indonesian press. The change of narration in media resulted from the efforts of a group led by a Protestant pastor, Herman Awom [Mote, Rutherford 2001: 125]. Indonesians from other islands finally could get unbiased information about the effects of the regime's policy and activities in West Papua. In optimistic atmosphere, Papuans displayed a local flag in a public space. Jakarta guaranteed freedom of speech to the indigenous people [McCulloch 2001: 104]. Everything seemed to move to the right direction full autonomy or independence.

Law No. 21/2001 granted West Papua a status of special autonomy within the Indonesian state (Otonomi Khusus Bagi Provinsi Papua, OTSUS). But the highest authorities rethought its accommodating policy in relations with West Papua. They were afraid that it could lead to the independence as in East Timor. It was an unacceptable scenario because Papua was more precious with its natural resources. To calm the separatists desires, President Megawati Sukarnoputri tried to issue a presidential directive dividing Papua into three provinces: West Papua, Central Papua and Papua. ${ }^{6}$ Sukarnoputri claimed it was a response to the demands of people from the southern Merauke and Biak, where many internal migrants lived. They advocated for establishing a separate province that would have closer relations with Indonesia. Many indigenous Papuans considered this solution as a step backwards that was to weaken their communities and independence aspirations. The protests against the government plans were held in the hinterland, especially around Timika.

6 The full content of INPRES 1/2003 is available at http://papuaweb.org/goi/pp/inpres2003-1.html (access: 25.05.2018). 
Constitutional Court suspended the directive proposed by Sukarnoputri in 2004, but this situation said a lot about Indonesian attitude [Tomsa 2008: 79]. The autonomy of West Papua under full control was rather a continuation of the New Order's legacy.

Religion played a significant role in West Papua after the fall of Suharto. Christianity experienced a revival among indigenous people and grounded its position as an inherent part of their identity. The independence protests usually took place near churches [van den Broek, Szalay 2001: 81]. Papuans chose Catholic and Protestant places of worship because considered them as safe and powerful spaces. Clergymen were a trusted group, one of a few during the Indonesian domination. They tried to support their followers but also were ambivalent about their new role in the separatist movement. Priests and pastors could not remain indifferent to the Papuans' harms, however, they tried to avoid politicisation at all costs and maintain neutrality. They were afraid of supporting independence activism because it could destroy the legitimacy of their missionary activities.

Church of the Three Kings in Timika became the most important place for protesters. The symbolism of the building was very explicit. The main painting showed Jesus Christ with arms spread in a peaceful gesture and a map of West Papua on his chest with a sentence "Give us our freedom". Inside the church we also could find pictures of West Papua Army (Armi Papua Barat) fighting with a black bird ${ }^{7}$ or the Bible covered with the independent flag of the "Morning Star". The sentences on the walls warned against being a hypocrite (orang munafik) or fraternising with the Indonesian government to gain financial benefits or a better position in the local administration. This referred to the unofficial division among Papuan inhabitants. Not all of them supported the independence because Papua was not the territory of indigenous tribes anymore. It also comprised the growing number of internal migrants who definitely preferred to stay with Indonesia. Thus, the society divided into four groups: 1) "the governmental Papuans" talking about a fictional "development", 2) the hypocrites seeking profits, 3) the true Papuans fighting for independence, 4) the neutral natives who entrusted their fate in prayer [van den Broek, Szalay 2001: 81]. Lack of solidarity in society weakened the independence desires.

Indonesia looked at West Papua with growing concern and finally used force to maintain its position. The Indonesian Special Forces removed the Papuan flag from the pole in front of the Church of the Three Kings. It led to the riots that harmed 38 people. Their sacrifice took on a symbolic dimension. Since then, the church became a sanctuary for independence activists. Papuans, both Protestant and Catholic, who attended the Sunday masses in the Church of the Three Kings, decorated their bodies with the traditional paintings to express their pride and desire for separation from Indonesia [van den Broek, Szalay 2001: 84]. Despite reluctance to political and governmental affairs, churches played a spiritual role and became a safe space to manifest separatists views. But with time, priests and pastors noticed the power of Indonesia

\footnotetext{
7 The black bird symbolized Indonesia.
} 
and tried to come back to full neutrality. They removed all controversial paintings and symbols from places of worship that could show the support for independence.

For a long time, West Papua was an enclave of Christianity. It resulted from intensive missionary activities in $19^{\text {th }}$ and in the first half of the $20^{\text {th }}$ century. Internal migrations violated the stable religious structure, and the domination of Islam was increasingly evident. In 1996, the population of Irian Jaya was around 1.9 million people. In the capital, Jayapura, only $20 \%$ of the 90,000 inhabitants were indigenous people. They made up a substantial minority in the local administration [Farhadian 2013]. At the end of the $20^{\text {th }}$ century, about $25 \%$ of the West Papua's inhabitants declared themselves as Muslims (comparing with only 4\% at the beginning of the 1970s) [Upton 2009: 228; Suryadinata, Arifin, Ananta 2003: 103]. It may also be asked how the number of Islamic followers grew so fast in just 30 years. Increased conversions to Islam by Christian Papuans could be an answer.

After annexation to Indonesia, West Papua became a target of Islamic Indonesian and Saudi preachers, who carried out missionary activities ( $d a^{\prime}$ 'wah) through social organisations [Farhadian 2013]. Despite the state law prohibiting conversions among the followers of the monotheistic world religions, they tried to convince Christian Papuans to change their faith. Muslim preachers usually started with the village heads (kepala desa), whose decision about conversion was binding for the entire settlement. In return, they received a reward - pilgrimage to Mecca. The preachers also promoted sending children to Islamic boarding schools (pesantren) in Java. These places focused primarily on Muslim education and eradicated deeply rooted local habits or customs among young Papuans. It included eating pork meat, drinking alcohol or smoking tobacco.

Besides preaching activities, the strengthening of the Islamic fundamentalist parties and organisations could be observed. They got voice back after the fall of New Order and saw it as an opportunity to turn Indonesia into an Islamic republic. The rise of extremists, who wanted to introduce a law based on religion (Shari 'ah) was visible. Indonesian Armed Forces (Tentara Nasional Indonesia, TNI) and police were weaker without Suharto so they did not engage in suppressing activities of the fundamentalists in the public sphere. Groups such as Islamic Liberation Front (Front Pembela Islam, FPI) or Laskar Jihad felt more confident. Some officers and soldiers even collaborated with the radicals in the new reality [Wanandi 2002: 107]. The chaos across the archipelago meant that the problem of resolving fundamentalism was postponed.

One of the Laskar Jihad's commanders trained in Afghanistan - Jafar Umar Thalib - exploited the chaotic and unstable situation in West Papua. His organization opened offices in several Papuan towns. They operated as Muslim communication platforms Ahlus Sunah Waljamah [Scott, Tebay 2005: 606]. The number of Laskar Jihar members in West Papua grew with ethno-religious conflicts in neighbouring Moluccas [Braithwaite, Duhn 2010: 167-168]. They fought there against Christians for a few months between 2000 and 2002. Later, they moved to the east, and then in 
Fak-fak and Sorong there were reported the cases of military provocations. Papuans believed that Laskar Jihad activities aimed at opposing the followers of different religions against each other [Ballard 1999: 472]. Fundamentalists also supported militants willing to fight with Papuan Christian separatists [Scott, Tebay 2005: 606]. The indigenous people were afraid of an outbreak of religious conflict because it would affect the weak position of West Papua. Here they had a common position on this issue with Jakarta. The government officials had to overcome the conflict between Muslims and Christians in Moluccas - the other one, in a short time, would imply Indonesia's inability to maintain a stable situation after the fall of New Order [Wanandi 2002: 108]. Stronger declarations against radicals came after the Jemaah Islamiyah ${ }^{8}$ bomb attack in Bali in 2002. Since then, the government stopped tolerating organisations, which had any connections with terrorism, including Laskar Jihad.

Reality hates the vacuum and fundamentalist Salafis quickly filled the gap after Laskar Jihad. They established foundations (yayasan) in some Papuan towns to promote Islam 9 . Its members supported various conspiracy theories about foreign financing of Papuan separatism because of high interest about hidden natural resources [Indonesia: Communal Tensions... 2008]. Salafis claimed that they are the only people who could restore the indigenous people to their rightful place in the Indonesian society. One of the tools they needed was Islam. It made radical Muslim organisations popular not only among migrants but also attracted the attention of Christian Papuans, who were disappointed with separatist movement.

The rising star among fundamentalists in West Papua was Al-Fatih Kaaffah Nusantara (AFKN) with its the charismatic leader, Muhammad Zaaf Fadzlan Garamatan. In one interview he said that Papuan Muslims led the resistance movement against colonialism and then fought for annexation of West Papua to Indonesia [Indonesia: Communal Tensions... 2008]. He accused Christians of collaboration with the Free Papua Organization (Organisasi Papua Merdeka, OPM) and attempted to establish a religious state. In other words, Fadzlan defended his organisation using the arguments which were often put against AFKN. He claimed that the statistical domination of Christians in West Papua was the matter of wrong methodology because they regarded animists as their coreligionists [Indonesia: Communal Tensions... 2008]. This interview made him famous for spreading misinformation between Muslims and Christians for his own purposes. But not all Islamic organisations pursued such an aggressive policy. The biggest one, Muhammadiyah and Nahdlatul Ulama promoted a moderate and peaceful message [Farhadian 2013]. They respected the law and focused on existing Muslim communities, but their presence confirmed the growing position of Islam.

\footnotetext{
8 Terrorist organization active in Southeast Asia.

9 Salafi movement connected with Hizbut Tahrir Indonesia (HTI). Indonesia: Communal Tensions in Papua, International Crisis Group, June 2008, http://www.ecoi.net/file_upload/2107_1307342933_neu. pdf (access: 20.05.2018).
} 
Islamic activities were a challenge to the Catholic and Protestant churches in West Papua. They tried to keep on their followers without accusations of involving in actions against Islam or Indonesia. This was a great challenge for the priests and pastors who had to balance between the state and the indigenous communities. It was difficult because of an emotional connection with the local environment. The clergymen were one of the few people who noticed the negative social consequences of transmigration. They wanted to help Papuans to deal with the exploitative attitude of internal migrants. Their main agenda contained the education of indigenous people and conversions of isolated tribes. The Church became not only the place of worship but also a learning centre for Papuans. Focusing on social issues was the strategy to slow down the spread of Islam.

Among other factors that violated the position of Christianity were Pentecostal movements with their charismatic leaders, which emerged in the first decade of the $21^{\text {st }}$ century. Their activity involved a simple strategy of conversions among Muslim communities that caused controversies due to their hidden links to the Indonesian government or the army. This was the reason why Pentecostal movements were accused of weakening the position of Christianity and spreading doubts and disunity among Papuans. Some congregations, such as Bethel and Betani, were even known for their religious intolerance towards Muslims [Warta 2010]. Despite the marginal influence on society, the media regularly made their opinions public. This situation raised the hoaxes and suspicions among Muslim internal migrants about the possibility of forced Christianisation. Moderate churches had to face a hard challenge to promote a more peaceful attitude and prove their neutrality. Their superiority over radicals laid in well-organised headquarters with responsible, transparent leaders [Indonesia: Communal Tensions... 2008].

The tensions between Muslims and Christians revealed the new tendency in West Papua - the progressive politicisation of monotheistic religions. This was a natural consequence because all religious leaders were - directly and indirectly - involved in current political events. For many Papuans, the well-educated priests and pastors were the only trusted representatives, much more reliable than Indonesian officials. Only their cautious approach was disappointing for some people, especially those engaged in the separatist movement. But they understood that the clergy was the only group that could hinder the process of Islamisation.

\section{INTERRELIGIOUS DIALOGUE UNDER NEW CONDITIONS}

After the fall of Suharto's regime, both Muslims and Christians in Papua reported incidents such as arson attacks on mosques and churches [Farhadian 2005: 3]. The local activists alerted about potential destabilisation that could be connected with Indonesian militants or separatists. These actions led to the decreasing support for OPM among Papuans. The church, initially enthusiastic, also became 
reluctant towards the separatists who tried to regard Christianity as part of their movement.

To avoid accusations of political bias, the Christian congregations engaged in peaceful reconciliation regarding human rights. The clergy declared that Papua should be the "Land of Peace" with no prejudices. Priests and pastors believed that they could achieve this with the help of activists from local non-governmental organisations (NGOs) who were interested in the situation in West Papua. After 1998, many initiatives promoted dialogue and the culture of peace. One of them was the Law and Peace Bureau (LPB) under the auspices of Catholic Church in Jayapura [van den Broek 2006: 71].

The effectiveness of interreligious dialogue rested in small projects and open assemblies, which brought people together, regardless of religion. The finest example was a common prayer in Jayapura on 21 September 2002, during the International Day of Peace. The representatives of Catholicism, Protestantism, Islam, Buddhism and Hinduism made a very strong appeal for peace that was positively noted in media. After this event, they established the Papuan Peace Day on 5 February [Tebay 2005: 11].

The peaceful initiatives were rather symbolic. Their leaders expressed a strong desire for interreligious dialogue to prevent a potential sectarian conflict. But they only focused on general goals like developing social organisations, which would care for religious issues along with access to education or medical care [Warta 2010]. The peace activists were not eager to engage in controversial issues, so they avoided discussing the growing anomie between Muslim migrants and local Christians. On the one side, there were the indigenous people who feared about Indonesia and perceived the Muslim consolidation as part of the hidden Indonesianisation. On the other, there were internal migrants who had their own cultures and traditions that had a significant influence on Papuans. The inhabitants of West Papua were confused and they did not know how to manage their status in such an unpredictable situation.

Maintaining a stable religious situation was difficult because of incidents that often happened in local communities and were of interest outside the provinces of Papua and West Papua. There were many mysterious cases connected with Christian priests who often were victims of Indonesian army. West Papua became an important territory after the fall of Suharto. It was the place where the soldiers still could demonstrate their power and share it with the state. Some of their minor actions had tragic consequences, e.g. in 2004, when they killed a well-known priest Eliza Tabuni and his son in the town of Monia [Żuchowski 2015: 94]. Similar incidents happen every year. Papuan militants do not leave them without a response because they also organise actions against the Indonesian army. There are many victims on both sides.

The escalation of violence against priests and pastors was common. It was connected with their activity in reporting the cases of human rights abuses to the organisations outside the province. The leaders of Protestant and Catholic churches prepared common reports regarding the incidents that happened between 2003 and 2006. Neither local separatists nor Indonesian soldiers were satisfied with their 
content because both sides engaged in aggressive actions [van den Broek 2006: 71]. The religious issues, however, were overshadowed by the political conflict, which resulted in the lack of trust in society. In fact, nobody wanted to fall into a local war, keeping in mind the bloody examples from Kalimantan and Moluccas.

Whereas the serious conflict was possible to avoid, the small clashes such as the one in Manokwari between 2005 and 2007 were quite probable. The dispute began with the protest of Christians opposing the construction of a mosque on the island that was a symbolic place of baptism of West Papua in $1855^{10}$. Many Papuans perceived this territory as a Christian enclave resistant to the influx of Muslims [Timmer 2003: 3]. The arguments of both sides were broadly discussed and aroused reluctance among Islamic followers. They accused Christians of discrimination while the clergy expressed a need for mutual respect in religious matters [Indonesia: Communal Tensions... 2008]. They argued that building a church in Mecca or Medina would be impossible and the respect towards holy places should be reciprocal. Since then, the relations between religions have cooled down.

In response to the tense situation, a famous figure in West Papua - Neles Tebay - tried to launch an initiative to promote dialogue between Muslims and Christians. His project aimed to integrate the Papuans and non-indigenous people from other parts of Indonesia. He referred to the peace initiatives which took place after the fall of Suharto's regime. With fresh enthusiasm and experience, Tebay returned to more universal values, and focused on communal problems resulting from miscommunication [Conflict Management in Indonesia ... 2011]. What is important, he was against the involvement of international organisations in the local interreligious dialogue. Tebay believed that people from the outside cannot understand the complex situation in West Papua and their presence could only hinder the peaceful coexistence.

Regular reports from local and foreign journalists focused on controversial violent issues. The narrative about West Papua was biased and emotional that led to mutual accusations on both sides. Independence activists and supporters were very active in media when revealing controversial activities to confirm their use of violence against Indonesia. One example was the journalistic investigation about forced Islamisation of Papuan children [Bechelard 2014]. It questioned the transparency of relations between the Indonesian officials and radical Muslim groups, like AFKN. The article used limited information and presented Indonesia only in a negative light. It described the process of Islamisation applied by AFKN in West Papua. So the "agents" visited the poor Christian families and offered scholarships in Java to their children, but they did not mention the Islamic nature of education. Parents had no

10 The first documented mission came to West Papua on 5 February 1855, almost half a century before the Dutch administrative offices. Then, Carl Ottow and Johann Geissler set foot ashore at Mansinam, a small island near Manokwari. According to the local myth, they entrusted the island to Jesus Christ, which was a symbolic baptism of West Papua. This story has a fundamental value for the Papuans who claim that the island was put under the care of Christians, not the Muslims or the Indonesian state [Aritonang, Steenbrink 2008: 345-350]. 
idea that they agreed to send their sons and daughters to boarding schools (pesantren) where they experienced deep indoctrination. Also, AFKN promised to finance their studies at prestigious Islamic universities in the Middle East and a pilgrimage to Mecca [Indonesia: Communal Tensions... 2008].

The AFKN offer looked honest for Papuans and some of them accepted it, however, they did not know that activities of AFKN were against Indonesian and international law. The United Nations Convention on the Prevention and Punishment of the Crime of Genocide in Article 2(e) states: "In the present Convention, genocide means any of the following acts committed with intent to destroy, in whole or in part, a national, ethnical, racial or religious group, as such [...] (e) Forcibly transferring children of the group to another group" [UN Convention on the Prevention and Punishment of the Crime of Genocide 1951: 280]. The problem was that Papuans had limited access to information and they did not treat the AFKN activities as violating their rights. The officials also refused to inspect the problem.

AFKN members boasted about taking Papuan children to pesantrens and put conversions to Islam in their regular agenda. Fadzlan had a tendency to exaggerate but he wanted to indoctrinate as many girls and boys as possible [Żuchowski 2015: 102]. The story of two Papuan boys who escaped from the pesantren near Jakarta showed how they were treated there. They suffered from systematic physical punishments and mental abuses, and this was not the most controversial part of their story. They told that Muslim Javanese teachers wanted to remove the independence spirit among the young Papuans and demanded absolute religious obedience. ${ }^{11}$

Despite the alarming information, the government maintained neutrality. The independence activists raised an alarm that the "agents" activities were a deliberate Indonesianisation, which took place under the religious cover. Neglecting of education and health care in West Papua or ignoring disturbing information about AFKN indicated unofficial engagement of Indonesia. Meanwhile, the radicals had their own policy and they deliberately spread misinformation to divide the society. For sure, they shared one thing with Indonesians - they perceived indigenous Papuans as a backward population and desired to civilise their culture, economy, policy and religion. The locals felt like second-class citizens. Many of them had hopes for changes with an election of president Joko "Jokowi" Widodo (2014). However, the promises made during the election campaign did not improve the situation of Papuans.

In 2011, the population of both Papua and West Papua provinces was estimated at around 3.7 million. This year, for the first time in history, the number of migrants exceeded the number of indigenous people (54\% vs. 46\%) [Elmslie, Webb-Gannon 2013: 152-153]. This lack of balance in social structure was one of the many effects of transmigration which came to the light after 1998. Despite the government propaganda, many Papuans considered the influx of internal migrants as a tool to dilute

${ }^{11}$ For Suharto, the foundation of "Indonesian heritage" was Javanese culture and history so he perceived local traditions as a deviation from a utopian dream about a monolithic country [Smith Kipp1996: 110]. 
their identity. Whereas from Indonesia's perspective, the program was a huge success - bottom-up Indonesianisation of Papua took place without a regular, violent conflict.

Charles E. Farhadian noticed the systematic growth of Islam at the expense of Christianity [Farhadian 2013]. This was a root of growing reluctance between Muslims and Christians who became more sensitive and suspicious. The fragile interreligious dialogue was ineffective after shooting death of a fifteen-year-old Endi Wanimbo during a religious assembly in Karubuga in July 2015 [Police chiefs under fire... 2015]. Each side presented their own version of this incident. Non-indigenous policeman showed arrogance claiming that his colleagues had to open the fire because the boy disturbed Islamic prayers. Christians believed it was a deliberate murder which aimed at showing the power. The religious leaders issued a common statement to calm the situation, but animosity among believers were already too deep.

Benny Wenda, the head of the independence movement, added a separatist aspect to Wanimbo's death. He explained that the religious dimension was to cover the true reasons for the boy's struggle. Wenda blamed all for hindering peaceful coexistence and praised the tolerance towards indigenous Papuans [Police chiefs under fire... 2015]. Meanwhile, the Indonesian government in Jakarta had a good reason to wait out the tense situations connected with the actions against Papuans. Forecasts indicate that in 2030, indigenous Christians will represent only $15 \%$ of the entire population in provinces of Papua and West Papua [Elmslie 2007] and the processes of Indonesianisation or Islamisation would be completed peacefully, without the involvement of army or regular war.

\section{CONCLUSIONS}

The demographic trends show that in a few decades Papua and West Papua will assimilate with Indonesia. The decreasing number of indigenous people weakens the position of the separatist movement, whose activities move outside the provinces and into the Internet. This state of affairs undoubtedly draws attention of the international community, however, nothing has been done to change situation. Indonesia has achieved its goals without decisive military actions against the Papuans, using only the right approach to the population. This changed ethnic and religious structures in West Papua, especially through transmigration. To understand the real influence of this process, I showed how it developed over the years. The influx of internal migrants from other islands has had a serious impact on the existence of indigenous people. Transmigration contributed to subsequent population growth, especially among resettled Muslim families, which led to the dominance of Islam and external ethnic groups. The profound transformation of the religious and ethnic structures of West Papua has shown that the Indonesian policy was efficient and well calculated.

In terms of administrative matters, Papua and West Papua are closer to Indonesia than ever. But indigenous Papuans still try to protect the weak autonomy because 
they experience racism and discrimination outside the provinces. There are two possible scenarios for the future. The first one assumes that the higher participation of internal migrants in local policy and the economy would bring peaceful coexistence through their domination. It would require an equal redistribution of resources. In this perspective, an identity of indigenous people will dilute until they perceive themselves as Indonesians. The second possibility is the conflict arising from the policy of Jakarta. Natural resources exploitation, with international companies and government as sole beneficiaries, might create a sense of anomie, which in consequence, could trigger violent behaviour. In both scenarios, religion and ethnicity are not only a matter of identity but also a tool in the struggle for development. Thus, the processes of Indonesianisation and Islamisation are difficult to evaluate. On the one hand, they pushed economic progress, but on the other, became a political measure that violates the rights of indigenous people. The national motto of Indonesia is "Unity in Diversity", however, in the Papuan case, the desire of unity in Jakarta is stronger than diversity.

\section{BIBLIOGRAPHY}

Anderson, B. 1983. Old State, New Society: Indonesia's New Order in Comparative Historical Perspective, "The Journal of Asian Studies", vol. 42(3), pp. 477-496. DOI: https://doi.org/10.2307/2055514.

Anderson, B. 2015. Papua's Insecurity. State Failure in the Indonesian Periphery, "Policy Studies", no. 73, East-West Center, Honolulu, http://hdl.handle.net/10125/37598 (access: 05.06.2018).

Aritonang, J.S., Steenbrink, K. 2008. A History of Christianity in Indonesia, BRILL, Leiden.

Ballard, C. 1999. Blanks in the writing: Possible histories for West New Guinea, "The Journal of Pacific History", vol. 34(2), pp. 149-155. DOI: https://doi.org/10.1080/00223349908572899.

Bechelard, M. 2014. Papuan children taken to Jakarta to be converted to Islam, http://www.smh.com. au/world/papuan-children-taken-to-jakarta-to-be-converted-to-islam-20140301-33soq.html (access: 05.06.2018).

Braithwaite, J., Duhn, L. 2010. Maluku and North Maluku, [in:] Anomie and Violence: Non-Truth and Reconciliation in Indonesian Peacebuilding, J. Braithwaite, V. Braithwaite (eds.), ANU E Press, Canberra, pp. 147-242.

Conflict Management in Indonesia - An Analysis of the Conflicts in Maluku, Papua and Poso. 2011. The Indonesian Institute of Sciences, Current Asia and the Centre for Humanitarian Dialogue, https:// www.hdcentre.org/wp-content/uploads/2016/08/5ConflictManagementinIndonesia-June-2011.pdf (access: 05.06.2018).

Document INPRES 1/2003, http://papuaweb.org/goi/pp/inpres2003-1.html (access: 25.05.2018).

Elmslie, J. 2007. West Papua: Genocide, Demographic Change, the Issue of 'Intent' and the Australia-Indonesia Security Treaty, the paper presented during the conference "West Papua: Paths to Justice and Prosperity", the University of Sydney, 9-10 August 2007, http://sydney.edu.au/arts/peace_conflict/ docs/Indo\%20Solidarity\%20paper.pdf (access: 31.05.2018).

Elmslie, J., Webb-Gannon, C. 2013. A Slow-Motion Genocide: Indonesian Rule in West Papua, "Griffith Journal of Law \& Human Dignity”, vol. 1(2), pp. 142-166.

Farhadian, C.E. 2005. Christianity, Islam and Nationalism in Indonesia, Routledge, New York.

Farhadian, C.E. 2013. Religious Changes Afoot in Papua, "Perspective", https://www.etan.org/issues/ wpapua/2013/1312wpap.htm (access: 20.05.2018). 
Gietzelt, D. 1989. The Indonesianization of West Papua, “Oceania”, no. 59, pp. 201-221. DOI: https://doi.org/10.1002/j.1834-4461.1989.tb02322.x.

Hardjono, J.M. 1986. Transmigration: Looking to the Future, "Bulletin of Indonesian Economic Studies", vol. 22(2), pp. 28-53. DOI: https://doi.org/10.1080/00074918612331334814.

Hechter, M. 1975. Internal Colonialism. The Celtic Fringe in British National Development, 1536-1966, University of California Press, Los Angeles.

Indonesia: Communal Tensions in Papua. 2008. International Crisis Group, http://www.ecoi.net/file upload/2107_1307342933_neu.pdf(access: 20.05.2017).

King, P. 2004. West Papua \& Indonesia Since Suharto: Independence, Autonomy or Chaos?, University of South New Wales Press Ltd, Sydney.

May, R.J. 1992. The religious factor in three minority movements: The Moro of the Philippines, the Malays of Thailand, and Indonesia's West Papuans, "Contemporary Southeast Asia", vol. 13(4), pp. 396-414.

McCulloch, L. 2001. Disorder in Megawati's 'New' Indonesia, "IBRU Boundary and Security Bulletin".

Mote, O., Rutherford, D. 2001. From Irian Jaya to Papua: The Limits of Primordialism in Indonesia's Troubled East, "Indonesia", vol. 72, pp. 115-140. DOI: http://doi.org/10.2307/3351483.

Police chiefs under fire as police kill boy and inflame religious tensions, 20 July 2015, https://www.freewestpapua.org/2015/07/20/police-chiefs-under-fire-as-police-kill-boy-and-inflame-religious-tensions/ (access: 12.06.2018).

Ricklefs, M.C. 2001. A History of Modern Indonesia since c. 1200 (3 ${ }^{\text {rd }}$ ed.), Palgrave Macmillan, Hampshire.

Roosman, R.S. 1975. Operation Task Force: Rural Development in Irian Jaya, "Yagl-Ambu", vol. 2(2), pp. $158-168$.

Rutherford, D. 2008. Why Papua Wants Freedom: The Third Person in Contemporary Nationalism, "Public Culture", vol. 20(2), pp. 345-373. DOI: https://doi.org/10.1215/08992363-2007-029.

Scott, C., Tebay, N. 2005. The West Papua conflict and its consequences for the Island of New Guinea: Root causes and the campaign for Papua, land of peace, "The Round Table: The Commonwealth Journal of International Affairs", vol. 94(382), pp. 599-612.

Smith Kipp, R. 1996. Dissociated Identities: Ethnicity, Religion, and Class in an Indonesian Society, The University of Michigan Press, Ann Arbor.

Suryadinata, L., Arifin, E.N., Ananta, A. 2003. Indonesia's Population: Ethnicity and Religion in a Changing Political Landscape, Institute of Southeast Asian Studies, Singapore.

Suter, K. 1982. West Irian, East Timor, and Indonesia, Minority Rights Group, London.

Tebay, N. 2005. West Papua. The Struggle for Peace With Justice, Catholic Institute for International Relations, London.

Timmer, J. 2003. Narratives of government and church among the Imyan of Papua/Irian Jaya, Indonesia, State Society and Governance in Melanesia - Discussing Paper.

Tomsa, D. 2008. Party Politics and Democratization in Indonesia Golkar in the post-Suharto era, Routledge, New York.

Trajano, J.C.I. 2010. Ethnic Nationalism and Separatism in West Papua, Indonesia, Journal of Peace, "Conflict and Development", no. 16, pp. 12-35.

UN Convention on the Prevention and Punishment of the Crime of Genocide, http://www.ohchr.org/EN/ ProfessionalInterest/Pages/CrimeOfGenocide.aspx (access: 6.06.2018).

Upton, S. 2009. The impact of migration on the people of Papua, Indonesia. A historical demographic analysis, unpublished $\mathrm{PhD}$ thesis, University of South New Wales, http://papuaweb.org/dlib/s123/ upton/_phd.pdf (access: 15.10.2018).

Van den Broek, T., Szalay, A. 2001. Raising the Morning Star: Six months in the developing independence movement in West Papua, "The Journal of Pacific History", vol. 36(1), pp. 77-92.

Van den Broek, T. 2006. A Peace Mission: The Church Response to Conflict the West Papua Case, [in:] Papua Land of Peace: Addressing Conflict Building Peace in West Papua, J. Budi Hernawan (ed.), Office for Justice and Peace, Jayapura.

Wanandi, J. 2002. Islam in Indonesia: Its History, Development and Future Challenges, "Asia-Pacific Review", vol. 9(2), pp. 104-112. DOI: https://doi.org/10.1080/1343900022000036115. 
Warta, C. 2010. Not to Be Neglected: The Religious Landscape in West Papua, "Oxford Transitional Justice Working Paper Series", https:/www.law.ox.ac.uk/sites/files/oxlaw/warta-religioninwestpapua-final1. pdf (access: 24.05.2018).

Weber, M. 1978. Economy and Society, University of California Press, Berkeley.

Żuchowski, D. 2015. Zapomniany genocyd. Analiza praktyk ludobójczych Indonezyjczyków wobec mieszkańców Papui Zachodniej, "Studia Socjologiczno-Polityczne”, vol. 4(2), pp. 87-108.

\section{RELIGIA I MIGRACJE WEWNĘTRZNE W PROCESACH INDONEZJANIZACJI}

\section{ISLAMIZACJI PAPUI ZACHODNIEJ}

Abstrakt: Migracje wewnętrzne stanowią coraz większy problem w społeczeństwach wieloetnicznych. Indonezja jest jednym z najbardziej różnorodnych krajów na świecie i domem dla setek grup etnicznych zjednoczonych w ramach głównej idei - tożsamości narodowej. Jednak koncepcja ta pozostaje niejasna dla wielu Indonezyjczyków, szczególnie tych mieszkających poza centralną, przeludnioną Jawą i Madurą. Aby osiągnąć utopijną jedność, prezydent Suharto (1967-1998) wprowadził program „transmigracji”, który przeniósł ludzi z przeludnionych terytoriów na tak zwane „,wyspy zewnętrzne”. Oficjalne plany podkreślały jego gospodarcze i rozwojowe znaczenie, ale transmigracja była również politycznym narzędziem do wprowadzenia procesów indonezjanizacji i islamizacji. Korzystając z teorii wewnętrznego kolonializmu Michaela Hechtera, autorka popiera swój argument sprawozdaniami i dokumentami dotyczącymi przypadku Zachodniej Papui we wschodniej Indonezji. Terytorium z separatystycznym doświadczeniem i silnym pragnieniem wielkiej autonomii stanowi dobry przykład prób celowej indonezjanizacji i islamizacji. Przytłaczająca liczba wewnętrznych migrantów, jawajskich muzułmanów, stopniowo osłabiała jedność chrześcijańskich Papuasów. Brak równowagi między tymi grupami powoduje ciągłe napięcie w zmieniającym się społeczeństwie. Na podstawie tego argumentu przedstawiony jest wpływ migracji wewnętrznej w szerszym kontekście. Autorka zwraca uwagę na dynamikę struktury religijnej i etnicznej przed upadkiem reżimu Nowego Ładu i po nim i twierdzi, że procesy indonezjanizacji i islamizacji mają kluczowe znaczenie dla dalszego istnienia Papuasów i rozwiązań przyjętych przez państwo indonezyjskie.

Słowa kluczowe: Indonezja, Papua Zachodnia, indonezjanizacja, islamizacja, transmigracja

\section{BIOGRAPHY}

Simona Sienkiewicz, MA, received her BA and MA in International Relations and Asian Studies at the Jagiellonian University in Cracow. She also studied Islamic Studies at the State Islamic University Syarif Hidayatullah Jakarta and it boosted her interest about religious and ethnic issues in Indonesia. Currently, she is preparing a $\mathrm{PhD}$ dissertation about the dialogue between internal migrants and indigenous people in Seram Island, Indonesia. Her research is funded by the Polish Ministry of Science and Higher Education under the Diamond Grant program awarded to the most promising young researchers in the country. Besides her project, she is also interested in the issue of transmigration to Eastern Indonesia, the rights of ethnic minorities and the empowerment of women in traditional societies. E-mail: sim. sienkiewicz@gmail.com 